\title{
Modernidade e alegoria em $O$ Conto da ilha desconhecida, de José Saramago
}

\author{
Majori Claro ${ }^{1}$
}

RESUMO: O presente trabalho pretende investigar a construção simbólico-alegórica do livro $O$ conto da Ilha Desconhecida, de autoria de José Saramago. Partindo da comparação com o universo dos mitos e dos contos de fada e caminhando em direção às narrativas contemporâneas. $\mathrm{O}$ artigo acaba por situar a obra analisada num terreno intermediário, moderno e parabolar, marcado pelas alegorias, utilizando-se de conceitos propostos por Walter Benjamin e reapresentados por Jeanne Marie Gagnebin a respeito do valor da alegoria na modernidade. Este trabalho também caminha no sentido de identificar, no texto analisado, o dilema do homem moderno.

ABSTRACT: The aim of this paper is to investigate the symbolic-allegorical construction of the novel The Tale of the Unknown Island, by José Saramago. Based on the comparison with the universe of myths and fairy tales and moving towards the contemporary narratives, the article ends by presenting the analyzed work in a middle ground, both modern and with parables, marked by allegories. Using the concepts proposed by Walter Benjamin and restated by Jeanne Marie Gagnebin about the value of the allegory at modernity, this paper goes on to identify, in the analyzed text, the dilemma of the modern man.

PALAVRAS-CHAVE: Símbolo; Alegoria; Modernidade.

KEYWORDS: Symbol; Allegory; Modernity.

Embora $O$ conto da Ilha Desconhecida seja um livro, pois foi publicado separadamente, ele denuncia, já em seu título, o gênero ao qual pertence - o conto -, e tem dele a extensão e a estruturação, se levarmos em conta os conceitos de Poe e Cortázar, sobre o conto ser uma narrativa breve de grande intensidade, cujo intuito é nocautear o leitor, fazendo com que as amarras narrativas o mantenham sem fôlego até o desfecho.

Ao contar a história de um homem que ousa pedir ao rei um barco para sair em busca de uma Ilha Desconhecida, o enredo linear caminha apressado rumo ao desfecho, contando sem delongas a obtenção deste favor e os preparativos do protagonista para sair ao mar em viagem. Os detalhes são suprimidos em favor do andamento da narrativa: não há floreios na caracterização das personagens, nem na apresentação do espaço. Os diálogos são transcritos de forma direta, apenas com a utilização de vírgulas para separar os enunciadores, cujas falas são demarcadas pelo uso da letra maiúscula no

${ }^{1}$ Mestranda da PUC - SP. 
início de cada sentença. Em determinados momentos, chega-se mesmo a fantasiar um cansaço, quase um descuido do escritor que - para dar conta de transmitir logo a sua mensagem - faz uso de um narrador primitivo e precipitado, o qual não faz questão de camuflar sua composição.

O conto da Ilha Desconhecida é um livro contemporâneo, mas sua estrutura fabular parece remeter aos contos maravilhosos ou à parábola, pois não há datação no texto, tampouco há a presença de elementos que façam o leitor inferir sobre ser esta uma narrativa atual ou não. Pelo contrário, tudo aponta para o contexto do "Era uma vez" dos contos de fadas, tempo remoto de uma terra longínqua, habitada por princesas, cavaleiros e dragões. Para personificar a autoridade, por exemplo, o autor escolhe um rei, que é uma figura atemporal. Este rei tem um palácio, diversos subalternos e um reinado - presenças constantes na literatura maravilhosa. Segundo Nelly Novaes Coelho:

O universo da literatura maravilhosa (...) está visceralmente ligado ao mundo mágico dos símbolos, mitos e arquétipos. É neles ou por meio deles que essa literatura é engendrada e se transmite aos homens através dos milênios (COELHO, 2008, p.91).

Para alguns estudiosos, o rei seria símbolo do poder mediador entre o divino e o humano, representante escolhido por Deus perante os homens no exercício da justiça e da nobreza. Nos contos de tradição oral e nos mitos em geral, se o rei, na qualidade de pontífice, torna-se injusto ou usurpador, todo o reino perece com a infertilidade e o infortúnio e, deste modo, o velho rei tem de ser morto ou deposto, e rapidamente substituído por um jovem rei a fim de que a prosperidade possa voltar ao reino. Consultando o Dicionário dos Símbolos, percebemos que no nível intrapsíquico,

o rei é também concebido como projeção do eu superior (...) Sua imagem concentra sobre si os desejos de autonomia, de governo de si mesmo, de conhecimento integral, de consciência. Nesse sentido o rei é, como o herói, o santo, o pai, o sábio, o arquétipo da perfeição humana, e ele mobilizava todas as energias espirituais para se realizar. (CHEVALIER; GHEERBRANT, 2001, p. 776).

Entretanto, o rei de Saramago não cumpre esta função de mediador sagrado. Nem em seu aspecto bem sucedido - o de representante da justiça divina -, nem na personificação contrária cujo trágico desfecho acaba por afirmar, em sua negatividade, a necessidade destes mesmos ideais. Nem digníssimo nem usurpador, o rei ao qual recorre o protagonista do conto de Saramago é hedonista, patético, vaidoso e bobalhão. Sua 
única preocupação é a de receber obséquios. Ele está tão aprisionado na própria necessidade de ser adulado, que passa os seus dias sentado à "Porta dos Obséquios", incapaz de interagir com outras necessidades, quer sejam suas ou de seus súditos. Se em muitos momentos o narrador nos fala em palácio, pajens e trono do rei, quando enfim pensamos que o visualizaremos sentado no trono aveludado de seu palácio magnífico, é de uma estrita cadeira de palhinha situada na varanda de uma casa que o vemos despachar. Do mesmo modo, quando esperaríamos vê-lo delegando afazeres a um Alto Conselheiro do Reino ou a um antipático Grão-Vizir, o que o narrador nos conta é que aquela que transmite a palavra do rei ao seu reinado é a mulher de limpeza, a qual, por falta de mais subalternos, cumpre tripla função: é, ao mesmo tempo, faxineira, costureira e arauto do rei.

O mesmo se dá com o protagonista do conto. Se o herói, simbolicamente, guarda parentesco com o rei, no sentido de ser um homem que, conectado com forças superiores, imbuído de ideais superiores e agindo em nome da coletividade ousa desafiar o desconhecido ou almejar o que os homens comuns não costumam almejar, e que, por meio de sua desmesura, acaba por engendrar um final glorioso ou trágico para si, o herói do conto de Saramago não é um herói, na medida em que só tem olhos para a sua reivindicação e carece da nobreza característica do herói clássico.

Tampouco se trata do anti-herói moderno, cujo foco fixa-se em seus traços individuais, em suas idiossincrasias e na mediocridade de sua constituição humana. Neste conto de Saramago, o herói não tem individualidade, não é descrito em termos de traços físicos ou de personalidade, não se afoga nas mazelas da existência. Ele não tem um nome, é referenciado apenas como "o homem", "o homem que queria um barco" e, posteriormente, "o homem que ganhou um barco". Nem herói, nem anti-herói, antes um esboço de herói rapidamente desenhado.

Deste mesmo modo rudimentar são apresentadas as outras personagens: nem o rei, nem seus subalternos, nem seus súditos têm nome. Da mulher da limpeza pouco se sabe, a não ser as tarefas para as quais foi designada. No fim do livro, numa tímida humanização de sua figura, ela surge precariamente como "mulher", sendo pela primeira vez retiradas as palavras referentes à sua função social. E sabe-se que era bonita, ou que pelo menos assim era apreciada pelo homem do barco.

Personagens que não têm personalidade. Herói que não se fala a partir desta condição nem de sua contrária. Narrativa maravilhosa de imagética simplória que foge às suas próprias leis. Símbolos que se desmontam, pois não faíscam a imediaticidade 
que une significante e significado, mas que tampouco se aniquilam empurrando a narrativa para o campo do particular. Narrativa moderna que não dispõe das pequenezas humanas para desenhar o mundo. Neste reino sem rosto, o que pretende, pois, Saramago narrar?

A despreocupação em construir um enredo bem engendrado, assim como a supressão, no texto, de elementos que caracterizem o espaço, o tempo e as personagens como figuras encarnadas numa história pessoal, deixam claro que a narrativa não pretende narrar o que promete, e que tais informações não se fazem necessárias, uma vez que a história que se pretende contar é uma outra história, camuflada sob a narrativa óbvia e operante nos subníveis do texto.

No entanto, se fica claro o desejo de contar uma outra história subjacente à história anunciada, a camada externa da narrativa não reflete, tal qual espelho límpido e fidedigno, a relação intrínseca entre os dois níveis, como costuma acontecer nas narrativas de caráter simbólico. Aqui, significantes lascivos, preguiçosos, caricaturais e paródicos são destinados a refletir significados que a eles se ligam por fios tênues, como se, do amálgama anteriormente existente, áreas de erosão tivessem garantido a descolagem e a conseqüente abertura para a conexão de significados outros. Sai-se, portanto, do reino imediato do símbolo para situar o texto $O$ conto da Ilha Desconhecida, de José Saramago, numa estrutura narrativa parabólica, cuja sobreposição de níveis se dá por meio da alegoria.

Jeanne Marie Gagnebin (1990), em texto que discute as ideias de Walter Benjamim sobre alegoria, morte e modernidade, diz que Orígenes previa três níveis de leitura, sendo o primeiro o literal, ao qual qualquer leitor tem acesso, o segundo, o moral, ao qual poucos leitores teriam acesso, e, por fim, o terceiro nível, o alegórico, o qual só os capacitados poderiam adentrar. E mostra que, se a forma alegórica de interpretação surgiu como prerrogativa espiritual dos iniciados, Lutero, ao questionar a palavra mediadora do sacerdote, aproximou esta abordagem do homem comum. E explica:

Aos olhos deste novo pensamento científico, a interpretação alegórica não oferece nenhum fundamento seguro: nascida da necessidade de conciliar o teor canônico com as exigências da razão e da moral, a interpretação alegórica pode mesmo construir uma ligação entre o sentido e a imagem, mas ela se mostra incapaz de estabelecer a necessidade desta ligação (...) É nesta arbitrariedade da relação significante-significado que vai esbarrar a crítica moderna da 
alegoria, uma arbitrariedade que tem seu fundamento no hiato entre sagrado e profano (GAGNEBIN, 1990, p.33)

Ao distinguir símbolo de alegoria, a autora afirma que:

Enquanto o símbolo, como seu nome indica, tende à unidade do ser e da palavra, a alegoria insiste na sua não-identidade essencial, porque a linguagem sempre diz outra coisa (allo-agorein) que aquilo que visava, porque ela nasce e renasce somente dessa fuga perpétua de um sentido último. A linguagem alegórica extrai sua profusão de duas fontes que se juntam num mesmo rio de imagens: da tristeza, do luto provocado pela ausência de um referente último; da liberdade lúdica, do jogo que tal ausência acarreta para quem ousa inventar novas leis transitórias e novos sentidos efêmeros. (GAGNEBIN, p.38)

Neste mesmo texto, Gagnebin mostra que, para Benjamim, a alegoria tem suas raízes na caducidade de nossas palavras, na efemeridade da vida revelada na experiência histórica e na morte do sujeito clássico que perdeu para sempre suas convicções sobre permanência e perenidade. Este novo sujeito, desgarrado de um sentido último para a existência, lida com objetos também efêmeros e desintegrados. Se sujeito e objeto são alçados à condição de coisas transitórias, a linguagem reflete esta condição na descolagem da relação intrínseca entre significante e significado. É a morte que se instaura como guia deste novo tempo, no qual o paraíso épico está para sempre perdido.

Voltando ao texto de Saramago, percebemos que, ainda que não haja datações, há a noção clara de que, qualquer que seja o tempo da narração, este, com certeza, não é o tempo mítico do símbolo. Isto fica muito claro no episódio da entrega do barco. Depois de ter conseguido junto ao rei a permissão para viajar em busca de uma Ilha Desconhecida e dele ter recebido a embarcação como presente forçado, o homem vai à doca e espera que o capitão lhe diga qual barco lhe seria destinado. O rei havia dado claras instruções: "Entrega ao portador um barco, não precisa ser grande, mas que navegue bem e seja seguro (SARAMAGO, 1998, p. 20)". Diante desta recomendação, o capitão lhe diz:

Vou dar-te a embarcação que te convém, Qual é ela, É um barco com muita experiência, ainda do tempo em que toda a gente andava à procura de ilhas desconhecidas. Qual é ele, Julgo até que encontrou algumas, Qual, Aquele. (...) Parece uma caravela, disse o homem, Mais ou menos, concordou o capitão, no princípio era uma caravela, depois passou por arranjos e adaptações que a modificaram um bocado, Mas continua a ser uma caravela, Sim, no conjunto conserva 
o antigo ar, e tem mastros e velas, Quando se vai procurar ilhas desconhecidas, é o mais recomendável (SARAMAGO, 1998, p. 28).

Embora as Caravelas fossem navios de pequeno porte, de três mastros, um único convés e ponte sobrelevada na popa - embarcações simples, portanto -, vale atentar ao fato de que elas estão associadas a um portentoso período da história portuguesa, um passado mitificado de intenso poder e de grandes conquistas, transmitindo a própria ideia do tempo épico de Portugal. Segundo o capitão, são as embarcações mais recomendáveis para sair em busca de Ilhas Desconhecidas. No entanto, é ele também quem diz que o barco passou por muitas adaptações, pois as personagens já não estão supomos nós - nos tempos das Grandes Navegações. Sendo que no momento em que se dá a narrativa, as Caravelas fazem parte do passado e ninguém mais sai em busca de novas terras. O próprio rei, ao ouvir a petição, garantiu ao homem suplicante que já não havia Ilhas Desconhecidas, pois todas elas já tinham sido descobertas e catalogadas pelos geógrafos do reino. Assim, do tempo no qual se constrói essa nossa história, somente uma coisa se conhece: é um tempo em que a ideia de paraíso está perdida, em que já não existem chamados para a aventura, quando pouco ou nada se tem a conquistar.

Ao falar da aventura no romance moderno, Milan Kundera (1996) afirma que o sujeito histórico, lançado à sua própria sorte, perde o fio de ligação com o sentido da existência, encolhe-se, duvida e submete-se àquilo que constitui sua nova verdade: a efemeridade da vida. No mundo moderno, a aventura é controlada e a ilusão de busca não mais se justifica. Não há mais Pátria ou Helena pela qual lutar. A aventura torna-se, deste modo, paródia de si mesma.

No texto de Saramago, isto fica muito evidente. O herói da aventura, sem nome e sem caracterização, pouco sabe de si mesmo e do mundo que o cerca. Ao contrário das outras personagens, seres fragmentados conhecidos apenas pelo papel social que exercem, tal como ser rei, ser capitão ou ser a mulher da limpeza, Ele nem mesmo isso conhece bem.

O diálogo com a mulher da limpeza assim prossegue:

Tens com certeza um mester, um ofício, uma profissão, como agora se diz, Tenho, tive, terei se for preciso, mas quero encontrar a ilha desconhecida, quero saber quem sou eu quando nela estiver, Não o sabes? Se não sais de ti, não chegas a saber quem és (SARAMAGO, p. 40). 
Des-identificado com seu papel social, só se reconhece pela sua necessidade de obter um barco para encontrar uma ilha. No diálogo acima descrito torna-se claro que partir em busca de tal ilha é sair em busca da própria identidade desconhecida. Diferentemente das aventuras clássicas, nas quais o herói, se não completo é grandioso em si mesmo, e parte em busca de objetos do mundo, alheios ao seu próprio eu, aqui o herói lança-se na aventura cega de buscar a si mesmo e, com isso, finalmente conhecer o objeto de sua busca. Deste modo, é mais o objeto buscado do que o sujeito que busca, porque não chega mesmo a ser sujeito; antes, é fragmento: um ser unicelular em cujo núcleo há apenas um filamento: o desejo de obter um barco para procurar uma Ilha Desconhecida.

Há, portanto, um deslocamento do sentido de aventura que se inscreve na narrativa pela alegoria da ilha, a ilha aqui podendo ser interpretada como o homem moderno desgarrado do continente de origem e flutuante num mar incerto e assustador. E mais: se, alegoricamente, o homem é uma ilha, ele é, principalmente, uma ilha desconhecida, ausente dos mapas, ainda não conquistada, cujo conquistador deve ser ele mesmo, isolado na tarefa de ser sujeito e objeto do próprio conhecimento.

Se, como diz Jeanne Marie: "O símbolo é, a alegoria significa" (GAGNEBIN, p.34), e se cabe ao intérprete alegórico a tarefa de buscar uma dentre tantas possibilidades de interpretação, então que outros rastros alegóricos poderíamos perseguir? O que significariam o rei, o barco, o mar, a tripulação e a mulher nesta "outra história" que o narrador nos conta, enquanto conta a história que finge contar?

No começo do conto, vemos o homem diante da "Porta das Petições", exigindo audiência com o rei. O leva-e-traz de seu pedido, que caminha por todos os subsecretários até chegar à mulher da limpeza, e, a partir desta, empreende o percurso contrário, faz-nos erroneamente pensar numa cena kafkiana. Mas, ao contrário desta, na qual a consciência da personagem está alienada e tenta, com sofreguidão, compreender e acessar o significado das leis impostas - tentativa exaustiva, vã e frustrada -, no conto de Saramago a burocracia é paródica e assinala, não a obstrução do significado dos códigos legais, mas sua imbecilidade mesmo, pois para ter acesso ao rei basta indispô-lo com seus súditos, ameaçando assim sua dependência em relação aos obséquios que recebe. Este governante que Saramago trabalha de modo alegórico não significa o mediador justo ou usurpador do universo simbólico, tampouco o pai inacessível do mundo kafkiano, mas a autoridade frágil, hedonista, patética, vaidosa e vulnerável, vítima de sua própria necessidade de adulação. E sujeita, portanto, a subornos, 
infiltrações, negociatas, imprecações. É o que faz o homem que queria um barco facilmente conseguir o objeto de sua petição.

A tripulação, por sua vez, pode ser interpretada como a representação crítica da alienação humana, num mundo em que a alma outrora inquieta sucumbe à vida medíocre garantida pelas instituições. Em certo momento do texto, sabemos que o protagonista não consegue formar uma tripulação, porque, no tempo em que se dá a narrativa, os homens "não iriam tirar-se do sossego dos seus lares e da boa vida dos barcos de carreira para se meterem em aventuras oceânicas, à procura do impossível" (SARAMAGO, p.39).

Deste modo, “os barcos são maiores que o próprio rei”. Na página 18 do livro de Saramago, assim fala o homem: "Mais lhes pertencerás tu a eles do que eles a ti, Que queres dizer, perguntou o rei, inquieto, Que tu, sem eles, és nada, e que eles, sem ti, poderão sempre navegar". O barco, meio de transporte para atravessar o mar tenebroso (“O mar é sempre tenebroso", nos diz, em vários momentos, o narrador), é também o primeiro objeto de desejo da aventura, aquele que surge no nível literal do texto. No nível subjacente - o alegórico - sabemos que o homem anseia por si mesmo, terra desconhecida que pretende desbravar. Quando, no fim do conto, o homem sonha, vemos que os vários níveis do texto, tal como colocou Orígenes e o citou Gagnebin (1990), se unem, e os objetos cobiçados (barco, ilha e si mesmo) se unem, rompem a distância e se amalgamam num só significante.

Vejamos a cena: na primeira noite em que se apossa do barco, o homem sonha. Em seu sonho, ele parte rumo à ilha desconhecida, acompanhado da tripulação que, na vida da vigília, não havia conseguido reunir. Quando percebem que não chegariam a lugar algum, os tripulantes optam por aportar na primeira ilha que encontram, saindo às pressas e deixando a caravela à deriva. Eis que a terra e as sementes que transportavam e que se espalham no afã da fuga - acabam por transformar o próprio barco numa ilha. Deste modo, veículo da busca funde-se ao local buscado, deixando claro que a viagem e não o destino - é o que importa quando a busca é pela descoberta de si mesmo. Talvez, porque não haja mesmo um lugar fixo no âmbito da formação de identidade. Mutante e em eterno processo, o homem moderno é mais do que ilha isolada no mar tenebroso: é antes disso uma ilha-barco flutuante desgarrada do continente ao qual um dia pertenceu.

No conto, o barco é o ponto do encontro entre o homem e a mulher. Se ele o desejava desde o princípio a ponto de ousar pedi-lo ao rei, a mulher da limpeza, ao sair pela "Porta das Decisões", faz do barco um objeto de seu próprio desejo, pois o escolhe 
antes mesmo do capitão o designar. Segundo lhe garante o companheiro de viagem: "Gostar é provavelmente a melhor maneira de ter, ter deve ser a pior maneira de gostar" (SARAMAGO, p. 32). A união com a mulher parece ser de grande importância para o desfecho do conto. Pois o homem que obteve o barco andava tão ensimesmado em sua teimosia de buscar uma Ilha que ninguém conhecesse, que se tornou, antes mesmo de alcançá-la em sonho, quando o próprio barco lhe toma a forma, ele mesmo um ser ilhado, sem nenhuma relação com o outro. Tão ensimesmado, confirma o narrador, que, mesmo percebendo a mulher como bela e nutrindo por ela desejos de amor, ela "dorme a poucos metros e ele não soube como alcançá-la, quando é tão fácil ir de bombordo a estibordo" (SARAMAGO, p. 50).

No sonho do homem, a caravela transcende seus contornos históricos e ganha contornos bíblicos. Carregando bichos e aves, terra e sementes, mudas e plantas, homens e mulheres, ela é também a Arca que suporta o dilúvio e garante a continuidade da vida. Torna-se inevitável uma reflexão a respeito de se, ao colorir o barco com a temática mítica da Arca de Noé, Saramago não se aproveita do sonho da personagem campo simbólico por excelência, ainda mais sendo um sonho dentro de um sonho, pois é sonho ficcional - para escapulir da alegoria e cortejar o símbolo e, com isso, arejar com um pouco de esperança o seu leitor. Pois, quando a tripulação e os animais deixam o barco à deriva e a terra e as sementes finalmente se espalham recriando o mundo, o barco torna-se floresta flutuante, campo fértil e promissor. Quando está a ceifar os primeiros frutos, o homem vê a sombra da mulher. Tal encontro faz a quebra do momento onírico e a ponte para o estado de vigília. Os dois acordam abraçados, e o clima é de sensualidade e comunhão. Como se, ao sair de seu estado ilhado para incluir esta entidade - o outro -, por ele fosse salvo e redimido, tornando o destino, promissor. Porém, se realmente o autor contemplou o símbolo ao construir esta analogia, isto se deu nos moldes em que nos fala Gagnebin, quando explica que, para Benjamim,

se o símbolo lembra a harmonia orgânica de uma natureza redimida, ele resplandece só durante o tempo de um relâmpago, 'ele é como um relâmpago que subitamente ilumina a noite escura"” (Gagnebin, p. $35)$.

Pois, passado o sonho, as personagens retornam ao seu estado original. Continuam fragmentos desgarrados, sem nomes, desconhecedores de si mesmos e pertencentes a um mundo ainda constituído por reis patéticos, tripulação covarde e 
súditos alienados. No entanto, agora homem e mulher sabem que nome dar à caravela, não por acaso o mesmo nome do lugar que, juntos, se dispuseram a buscar: "A Ilha Desconhecida".

Talvez o autor esteja a nos lembrar que, se existe alguma esperança no mundo moderno, esta esperança não surge da certeza de que, no fim, tudo ficará bem. Antes disso, é uma esperança que nasce da legitimação do estado de desesperança crônica, no qual o homem, conhecedor de sua natureza desconhecedora e sabendo-se irremediavelmente ilhado, possa prescindir da ilusão de chegada e, a partir dessa desistência compulsória, fazer algo melhor de sua própria condição.

Quando o narrador conclui sua história dizendo que "Pela hora do meio-dia, com a maré, a Ilha Desconhecida fez-se enfim ao mar, à procura de si mesma" (SARAMAGO, p.62), percebemos que a aventura, como nós já esperávamos, não se completou. A única diferença é que as personagens agora adquiriram consciência da natureza de sua busca: uma busca que não cessa e que nunca cessará, porque não se dá em direção a um local fixo e concreto, localização geográfica, objeto externo, como acontecia no mundo de Ulisses ou na época das grandes navegações.

Todos os níveis do texto agora se revelam e a alegoria de Saramago torna-se, não símbolo único, mas uma dentre tantas outras alegorias capazes de expressar o dilema de todos nós: homens modernos flutuando à deriva numa aventura labiríntica e espiralada, de destino incerto e sem a garantia de chegada.

\section{REFERÊNCIAS BIBLIOGRÁFICAS:}

COELHO, Nelly Novaes. O Conto de Fadas: Símbolos - Mitos - Arquétipos. 1. ed. São Paulo: Paulinas, 2008.

CHEVALIER; GHEERBRANT. Dicionário de Símbolos. 16ª ed. - Rio de Janeiro: José Olympio, 2001.

GAGNEBIN, Jeanne Marie. História e narração em Walter Benjamin. São Paulo: Perspectiva, 1990.

KUNDERA, Milan. A Arte do romance. Rio de Janeiro: Nova Fronteira, 1986.

SARAMAGO, JOSÉ. $O$ conto da Ilha Desconhecida. São Paulo: Companhia das Letras, 1998. 